\title{
ENTRE-TEXTOS: LA DIMENSIÓN DIALÓGICA E INTERCULTURAL DEL DISCURSO POÉTICO MAPUCHE ${ }^{1}$
}

\author{
Mabel García Barrera \\ Universidad de La Frontera \\ mabelg@gmail.com
}

RESUMEN / ABSTRACT

Este trabajo aborda en el actual discurso poético mapuche cómo éste representa la perspectiva dialógica del cruce cultural a través del procedimiento transtextual, estableciéndose que este discurso, al poner en relación cánones discursivos y elementos culturales propios y ajenos, resignifica el canon poético occidental que le sirve de base, a partir de la inscripción de diferentes tipos de lenguajes y cánones propios; reelabora el sentido de premisas estéticas occidentales, a partir del sentido expansivo que adquieren los discursos metapoéticos vinculados al ethos cultural tradicional, y desplaza la perspectiva intercultural del discurso por un progresivo posicionamiento de un "discurso de indigenidad". Todo lo anterior, direccionado por las funciones metadiscursivas de recuperación y resistencia cultural de un discurso que busca una construcción de un sistema textual propio, y que se ancla en concepciones territorializantes sobre lo que es o debería ser la discursividad -o el intercambio discursivo- en el ámbito del contacto cultural.

Palabras Clave: poesía mapuche, relaciones interculturales, discurso indígena, transtextualidad.

${ }^{1}$ El presente trabajo forma parte del Proyecto FONDECYT Nº60359 "Discurso y Metadiscursos Mapuches: ¿Interculturalidad o Indigenidad?”, dirigido por el Dr. Hugo Carrasco Muñoz, donde participa como coinvestigadora la Dra. Verónica Contreras y la autora del artículo. 
This paper deals with the present poetic Mapuche discourse in terms of how it exhibits a dialogical perspective in a cross cultural transtextual procedure; it aims at establishing that this type of discourse stresses the western canon used as its support, including different types of language and uses its own cultural elements as well, that is, its own "canon"; by emphasizing the progressive location of an indigenous discourse, this discourse aims at cultural rescue and cultural resistance in terms of building its own textual system, anchored in territorial conceptions of what an indigenous discourse should be within a wider cultural context.

KEY WORDS: Mapuche poetry, cross cultural relationships, indigenous discourse, transtextuality.

\section{INTRODUCCIÓN}

El actual discurso poético mapuche -como las demás expresiones de arte urbano e intercultural: pintura, mural, escultura, teatro, audiovisual, música y relato, entre otras-, surge de los naturales procesos de adopción e innovación cultural que realiza este pueblo con el fin de responder a las necesidades expresivo-comunicativas que le demandan las relaciones culturales asimétricas con la sociedad chilena occidental; un marco históricopolítico en el cual tienen lugar estos proyectos artísticos como discursos de "la diferencia cultural" y, en este sentido, como espacios simbólicos de la rearticulación étnico-cultural y de negociación de significados (Bhabha, H. 2002).

Desde este punto de vista, resulta fundamental acercarse a los modos de representación que el discurso poético mapuche instala sobre este proceso, particularmente porque a través de él se visibilizan algunas estrategias vinculadas con la recuperación de las fronteras culturales en el ámbito de las prácticas de la comunicación intercultural. En este sentido, no se puede dejar de aludir a las complejas transformaciones que han tenido las funciones metadiscursivas de este discurso(Cfr. García, M. 2005b, 2005c), donde la más notable se establece a fines de la década de los ochenta, cuando se da inicio a una etapa de fortalecimiento en los proyectos poéticos e intelectuales de estos escritores, quienes se van posicionando en el medio nacional más conscientes de los recursos políticos y publicitarios que tienen sus textos, enfatizando particularmente la función performativa del discurso, al direccionarla hacia las problemáticas de la reivindicación y de la resistencia cultural.

Se abre así este espacio discursivo a la representación de la perspectiva dialógica-conflictuada que se ha construido sobre el cruce cultural como 
experiencia histórica, la que se inscribe como mecanismo de su articulación textual, expresándose en diversos elementos y procedimientos de carácter dicotómicos y transversales, y de cuya correlación surge el estadio simbolizador del texto que, como experiencia de lenguaje, afirma "in situ" la pervivencia de la cultura. En esta dirección, cabe reflexionar cómo la inscripción de textos de diverso origen al interior de los textos poéticos se sustenta en esta perspectiva dialógica que opera como catalizadora de los significados, invirtiendo los sentidos primarios al ser conducidos por la función performativa, afectando por lo tanto los aspectos semánticos y/o los formales del discurso, a diferentes niveles, con el fin de reterritorializar "la diferencia".

Me refiero con ello a la transtextualidad o la relación de textos en el texto (Genette, G. 1989; Lotman, I. 1996) como procedimiento discursivo, la cual puede ser explicada en su sentido y función al interior del mecanismo que Lotman describe como "mecanismo especular", el que se expresa, según este autor, mediante una actitud dialógica de simetría-asimetría que pone en juego diversos recursos para coordinar las relaciones textuales, generándose con ello una condición de pareja "simétrico-especular" que se convierte en su base estructural elemental.

La forma en que la transtextualidad actualiza esta relación dialógica en el discurso poético mapuche, vista ahora como pareja simétrico-especular, es mediante la vinculación que establece el sujeto textual entre los textos de la cultura propia y tradicional y de éstos con los de la cultura occidental y universal, dinamizando en el espacio textual por una parte, una lectura de apropiación e innovación de lenguajes, cánones y textos ajenos y, por otra, de retradicionalización y resignificación de los cánones propios -pewma, rito, mito y/o machi ül-, los cuales son articulados desde significados más complejos que tienen relación con el rango epistemológico que adquiere el discurso poético para la propia cultura y que sirve de apoyo para reflexionar y visibilizar la unidad o cohesión cultural relacionada con un concepto de "nación cultural y/o política" mapuche (Cfr. García, M. 2005a).

En esta dirección, habría que agregar que el proceso de transtextualidad genera diversas y complejas interrogantes sobre "cómo la cultura significa, o qué es significado por la cultura" en el ámbito traduccional (Bhabha, H. 2002:212), lo que lleva a plantear que en el caso particular del discurso poético mapuche estos significados surgidos del proceso dialógico transtextual y mediados por el sujeto textual, son orientados a diversos objetivos 
como: 1) la resignificación de la superestructura discursiva canónica del discurso estético occidental a partir de la inscripción estratégica e iterativa de diferentes tipos de lenguajes y cánones propios; 2) la reelaboración del sentido de premisas estéticas occidentales, a partir del sentido expansivo que adquieren los discursos metapoéticos de los proyectos poéticos vinculados al ethos cultural tradicional, y 3) el desplazamiento de la perspectiva intercultural en el discurso por un progresivo posicionamiento de un "discurso de indigenidad ${ }^{2 "}$; todos ellos, rearticulaciones y reinterpretaciones que en su conjunto colaboran con la construcción de un sentido textual de lo propio, y que se ancla en concepciones territorializantes sobre lo qué es o debería ser la discursividad -o el intercambio discursivo- en el ámbito del contacto cultural.

Desde este punto de vista, establezco que es la actitud dialógica de estos textos lo que produce el continuum semiótico del discurso poético mapuche, desde y en el cual se establecen las relaciones fronterizas de los significados textuales y donde acontece el mayor esfuerzo de traducción de textos que han tenido o tienen vida fuera de este sistema, textos que el sujeto textual traduce "a uno de los lenguajes de su espacio interno o (que) debe semiotizar (por ser éstos) hechos no-semióticos" (Lotman.I. 1996: 24) $)^{3}$ desde su perspectiva cultural.

\section{ENTRE-TEXTOS I: LA RESIGNIFICACIÓN DEL CÁNON POÉTICO OCCIDENTAL}

La insistencia por una lectura más allá de los sistemas semióticos, tal como lo ha señalado Bhabha (2002) refiriéndose a los discursos marcados por la

${ }^{2}$ Cfr. Desde el punto de vista de Stavenhagen, "el discurso de indigenidad" se encuentra en directa relación con los derechos humanos y los temas contingentes para los pueblos indígenas: la autonomía y la libre determinación, señalando que "el discurso de indigenidad conduce a la denuncia de injusticias (incluso crímenes) históricas cometidas contra los pueblos indígenas (genocidios, despojos, servidumbre, discriminaciones), y al planteamiento de derechos específicos que se derivan de estas injusticias y de la calidad de indígenas ("primero en tiempo, primero en derecho"; "recuperación de derechos históricos"). El discurso de la indigenidad fundamenta y legitima la demanda de derechos humanos específicos de los pueblos indígenas" (1995:117).

\footnotetext{
${ }^{3}$ Los paréntesis son míos.
} 
diferencia cultural, demanda la ubicación del contexto de producción particular donde acontece tanto el circuito de los significados y sus sentidos, como también de sus contradictorias emergencias y divergencias; así, en este espacio de contacto cultural, ambivalente y conflictuado, el actual discurso poético mapuche inscribe, desde su propuesta de origen, un sujeto textual que se instaura en y desde una focalización centrada en una pertenencia cultural específica, la ancestral; punto de vista desde el cual evalúa las relaciones individuales y colectivas con la sociedad occidental, particularmente la del contacto con la sociedad chilena. En este sentido, la transtextualidad como procedimiento del mecanismo de articulación textual dialógico contribuye a explicar la forma en que acontece el espacio de negociación de los significados culturales, la posición del sujeto frente a ésta, sus objetivos y las funciones discursivas y metadiscursivas en este proceso.

Considerando la vasta gama de posibilidades que ofrece la construcción de significados originados por los diversos procedimientos transtextuales, me parece importante revisar en este punto cómo el actual discurso poético mapuche, desde la década de los sesenta a la fecha, ha ido efectuando un desplazamiento paulatino del sentido de apropiación de la superestructura discursiva del canon poético occidental, al introducir, en el mismo espacio textual, cánones discursivos de la cultura propia tradicional, privilegiando con ello una estrategia de intervención que abre el espacio textual a la confrontación de significados estético-culturales y tipologías discursivas, en el amplio campo de lo que Genette ha llamado la architextualidad, lo que ha generado nuevos sentidos orientados a la recuperación y visibilización de los cánones propios.

Me refiero a un tránsito discursivo complejo de un discurso poético que ha debido ceñirse a tiempos y espacios política y simbólicamente establecidos por el fuerte proceso de homogeneización cultural -lo que ha determinado las condiciones de acceso a la escritura, a los cánones estéticos y culturales y, con ello, a los modos de producción y circulación textual.

1.- El primer encuentro: transposiciones, equivalencias y ensamblaje. $\mathrm{Si}$ bien, en su origen, los primeros antecedentes que se tienen sobre la poesía mapuche la vinculan al "ül" o canto tradicional; esta forma expresiva a inicios del siglo xx transita rápidamente de la oralidad a la escritura y con ello a la adopción de los cánones de la poesía occidental, aprendida generalmente en un sistema escolar que actúa como parte de los mecanismos 
de imposición cultural. En este proceso, los escritores de la primera mitad de siglo - Anselmo Quilaqueo, Guillermo Igayman, Teodoberto Neculman, Antonio Painemal, A. T. Antillanca- parecen reafirmar un texto poético monolingüe -en castellano-, adscrito a las tendencias poéticas imperantes y centrado en temas propios y/o universales, iniciando lo que Iván Carrasco ha descrito como "la fase de la escritura propia" (1990).

No es sino hasta la década de los sesenta que se puede observar que este paradigma entra progresivamente en crisis, cuando los proyectos poéticos de Sebastián Queupul y José Santos Lincomán (García y Galindo, ed. 2004) manifiestan los primeros rasgos de recuperación de códigos discursivos y elementos culturales propios. Así, mientras el primero escribe una gran parte de sus textos en castellano, "de acuerdo a las reglas de composición de géneros, métrica, retórica y semántica de la literatura occidental" (Carrasco, I. 2003:58), el año 1966 al publicar algunos textos en doble registro - mapudungun/castellano- bajo el título de Poemas mapuches. En castellano, se constituye, según Iván Carrasco, en el primer escritor mapuche que supera las convenciones de la etnoliteratura indígena y de la poesía chilena y contribuye a la creación de una poesía "etnocultural", al optar "por escribir poemas de doble textura que lleva implícito un doble destinatario y, por lo tanto, una lectura plural" (2003:62).

En esta misma condición de tensión cultural, que visibiliza un discurso poético sometido a constantes readecuaciones vinculadas a una identidad fragmentada, la obra poética de José Santos Lincomán, si bien da cuenta de un proceso escritural similar al de Queupul -textos en castellano con una retórica modernista, tendencia a la métrica regular, inclinación por la rima asonante alternada, de temática variada, y que busca mantener los códigos tradicionales de la cultura propia en los textos en "ce-sugun" (habla williche)-, desde el punto de vista de la recuperación de los cánones propios, será este proyecto el que se constituya en el mediador más significativo del proceso de transición del "ül" a la actual poesía escrita, al mantener y concebir el discurso poético como "ülkantun" o canto mapuche, resignificando el canon poético occidental mediante la autoidentificación de una voz poética que se visualiza a sí misma como "ülkantufe"(cantor) 4 .

${ }^{4} \mathrm{Cfr}$. "Yo soy un triste zorzal / me dijeron que era malo/ una mañana de verano/ antes que saliera el sol./ /En mi ruka no hay dolor/solo hay un cantar profundo/Así vine yo en el 
Se abre así el espacio textual a un proceso dialógico complejo que se hace cargo no solo del conflicto lingüístico y de su traducción cultural, sino también a un sentido de pertenencia a la cultura ancestral que irrumpe como decurso natural en las prácticas simbólicas que la vinculan de algún modo con la sociedad global. No obstante, en esta etapa, la formalización de dos tipos discursivos en el mismo espacio textual, sobre todo en el espacio otorgado al canon occidental, no constituye una instancia de mayor conflicto; esto debido principalmente a que las situaciones de la diferencia cultural inscritas en los textos son desplazadas hacia el ámbito semántico y/o hacia una imbricación estructural-formal.

Mientras en Queupul los textos poéticos más representativos de esta relación discursiva centran el conflicto del desarraigo cultural en una actitud de añoranza de lo propio, es esta misma actitud la que explica la traducción autorial de sus textos del castellano al mapudungun, manifestándose un procedimiento de equivalencia semántica y transposición que no logra invertir la estructura del tipo discursivo dominante por la del canto mapuche o "ül”, convirtiéndose así el bilingüismo en una readecuación de códigos que no subvierte los mecanismos arraigados por la imposición cultural; una readecuación que, en el caso de Lincomán, se explica como proceso de ensamblaje de las estructuras canónicas en la medida en que ambas aceptan a nivel retórico y/o narrativo algunas condiciones específicas de la otra; así la introducción y conclusión, propia del discurso tradicional, se adapta a la estructura del verso, estableciéndose como parte del cuerpo poético, lo que facilita además la mantención de una estructura narrativa compatible con el carácter enunciativo de los textos poéticos, mientras a nivel estructural se busca conservar el metro -predominantemente yámbico- $\mathrm{y}$ melodía de acuerdo al canon tradicional -acentuación

mundo/ mi sufrimiento es canción./ /Llegó temprano el halcón,/ viejo gorrión señalero./ Aquí vive un Wilqui viejo / que en su nido debe estar./ / Suena la puerta de mi ruka/ la tralca vas a entregar, / no hay tralca ni la conozco / pero al juez vas a llegar./..." ("El triste zorzal") (2004:93).

"Viejo Ancud, viejo Ancud,/ te venimos a saludar/ en tu soledad, en tu soledad,/ somos hijos de tus tierras / que labramos con afán/ con el hacha y el hualato/ para que nos des el pan./ Muchos años cantaron mis abuelos / también cantó mi papá/ cuando decía cantando/ ¡Chao Antü akuy moleu malen/ piapay piapay peñeira/ Edaukan Edaukan amuein!” ("Viejo Ancud") (2004:122). 
tonal hacia el final de verso (Cfr. Painequeo, H. 2000), articulándose todo lo anterior en una voz poética que busca una orientación cultural del texto como canto, inscribiéndose así este poemario además en las características más primigéneas del canon poético occidental.

2.- Los textos referenciales: el decir desde el lenguaje y el discurso tradicional. Establecido este antecedente, que marca el gradual proceso de intervención del canon poético occidental a partir de la inscripción de los cánones tradicionales propios, a fines de la década de los ochenta con la publicación de las obras poéticas de Leonel Lienlaf y de Elicura Chihuailaf se produce una etapa decisiva para la dirección que adquirirán los actuales proyectos escriturales.

Uno de los principales méritos de estas obras es la inclusión de una conciencia étnico-cultural e histórica desde la cultura propia, el rescate de la memoria ancestral, la denuncia del atropello histórico y el consecuente desarraigo cultural. En esta situación de conflicto cultural, el escritor debate su propia coherencia en la opción por un proceso de registro -oralidad/ escritura-, idiomático - mapudungun/castellano y discursivo -cánones propios/ajenos-; resolviendo esta tensión en un proceso traduccional que propone versiones adecuadas a las circunstancias de enunciación intercultural: la escritura bilingue y/o el collage etnolingüístico, en algunos textos la inserción de la representación manuscrita e iconográfica, junto a la tipográfica, en otros casos, la resignificación del discurso histórico oficial, destacándose otra alternativa más compleja desde el punto de vista estético, como es la construcción de un macrotexto cifrado culturalmente que a nivel superficial narrativiza denotativamente, mientras en la lectura profunda demanda la competencia interpretativa de la cultura tradicional.

En este sentido, el libro de edición bilingüe -mapudungun/castellano-, Se ha despertado el ave de mi corazón (1989), de Leonel Lienlaf, no solo busca denunciar explícitamente el genocidio cultural, sino también reivindicar los códigos ancestrales mediante la legitimación del decir desde el lenguaje y el discurso tradicional como instancia de significación y comunicación cultural; una estrategia que interviene el canon poético occidental a partir de una forma de comunicación tradicional: el lenguaje del "pewma" (sueño); código cultural altamente cifrado que se propone como articulador de los significados del texto, permitiendo sus desplazamientos entre los ámbitos de lo tangible y lo intangible, lo humano y lo sobrenatural; y cuyo propósito textual apunta a abrir los signos a la dimensión ritual y mítico-simbólica de la cultura que, representada mediante la disposición 
del poemario como "texto- kultrung"5 (cfr. Geeregat y Gutiérrez 1992), pone en crisis el soporte expresivo occidental (idiomático y canon) ante la evidente dimensión de ülkantun (canto mapuche) que privilegia la versión en mapudungun de la cual la castellana sería otra versión.

Refiriéndose a este proceso en particular, de un discurso que va "de la apropiación hacia la innovación cultural" (1993), Hugo Carrasco señala que en su primer libro "si bien se puede advertir la delicada sensibilidad poética y gráfica del autor al preparar la versión castellana y escrita del texto, éste se halla escrito originalmente en mapudungun y, al parecer, es un conjunto sistemático de ül", el que solo puede ser explicado en el contexto de los antiquísimos patrones creenciales que le subyacen.

La demanda de una competencia interpretativa intercultural se hace exigible ahora no solo para el reconocimiento de dos cánones discursivos en el mismo espacio textual, sino también para distinguir en o entre ellos los recursos creativos propios que caracterizan a un texto artístico y, junto a lo anterior, "leer" adecuadamente en la trama textual dos sistemas conceptuales y cosmovisionales diferentes. Esta compleja estrategia dialógica se desplaza, afectando tanto los aspectos semánticos como formales del texto e inscribe sus propios sentidos culturales en un sistema estético-comunicativo complejo.

Un ejemplo de este proceso, y que afecta simultáneamente los diferentes niveles textuales, surge de la ubicación anacrónica que adopta el sujeto de la enunciación, quien en un estado próximo al trance de "machi" se desplaza por el ámbito mítico-ritual, cruzando las coordenadas témporoespaciales, desde la cual potencia por una parte la revisión histórica de los acontecimientos de dominación pasados y presentes, y por otra se hace cargo de su propio tránsito en esta circunstancia, vinculando a estas perspectivas una orientación metadiscursiva eminentemente reivindicativa y de resistencia cultural.

Así, el texto "Rupamum", traducido en su versión al castellano como "Pasos sobre tu rostro", no solo referirá al viaje mnémico hacia el pasado histórico y ancestral, sino que además actualizará la visión ética-cultural del ciclo vital (Cfr. Cozzi, E. s/f), en la cual el antepasado "es" también la generación vigente, donde el "che" (la persona) asume en su presente no

\footnotetext{
${ }^{5}$ Tambor ritual sagrado del o la machi que representa la cosmovisión del pueblo mapuche.
} 
solo su propio devenir histórico y espiritual sino también las experiencias y el "ser" de sus ancestros:

Mi angemew

kimnoelchy takuwe tukuniey

ti dungun trayen

kuyfike pülli ñi trayen

Lelituenew ñi pewma

welu kimlan chemew.

Mi angemew tripan

mutrungreke

kiñe wepüñeñ ñi kuwü

mütrümenew.

mutrungreke trekan

chew ñi rupamum füchake antikuyem

ngümanmew, ayenmew,

dakinmew ñi pewma

ina pen kiñe cruz katrünmaetew ñi lonko

ka kiñe espada bendecipeetew petu ñi lanon. antes de mi muerte.

Güy pechymutrungen

mi rukamew, ñuke.
Madre, sobre tu rostro, con un traje desconocido

apareció el murmullo del agua

Todos los recuerdos presentes

envolvían ese sonido

y algo me miró.

Yo era un tronco formado

por miles de caras

que salían de tu rostro.

Por el tronco caminé a través

de cientos de generaciones

sufriendo, riendo,

y vi una cruz que me cortaba la cabeza

y vi una espada que me bendecía

Soy el tronco, madre

el que arde

en el fuego de nuestra ruka.

Poema y poemario despliegan su propio sentido ante la fuerte violentación histórica, un sentido que solo puede ser contextualizado en el marco de la interrupción de esta cadena vital y de las experiencias heredadas, abriéndose con ello un espacio de evaluación a las normas de comportamiento (cfr. Ibacache, J.; McFall,S.; Quidel, J. 2002), las que por una parte, homologan a las que afectan al sujeto de la escritura -quien debe buscar los recursos comunicativos y discursivos más adecuados para no transgredir este sistema creencial- y, por otra, desacralizan el discurso ético-cristiano occidental mediante el proceso de inversión de sus símbolos sacros.

En esta misma dirección, se marcan como significativos los poemas "Kuwü ñi aukan" ("Rebelión"), "Wüdko"(s/trad.), "Mañkean ñi dungu" (El sueño de Mañkean), "Llegün" (Creación), entre otros; textos en los cuales se problematiza el acontecer de la palabra (dungu), como un modo de registro: 
"Ñi kuwü / ailay wirialu/ kiñe fücha profesor/ ñi dungu//. Ñi kuwü/ ailay wirialu/ inchenodungu/ Ñiküfalu eimi/ pienew/ ñi kimngam ñi ñiküfün./ /Ñi kuwü feipienew/ mapu pepi wiringelay." ("Kuwü ñi aukan")

"Mis manos no quisieron escribir/ las palabras/de un profesor viejo./ / Mi mano se negó a escribir/aquello que no me pertenecía/ Me dijo:/“debes ser el silencio que nace"/ /Mi mano / me dijo que el mundo/ no se podía escribir" ("Rebelión")

- o como canon, en el cual se privilegia la acepción cultural del "ül” (canto):

“...Ti lelfün ñemy/ ñi gütrÜf-gütrüfchy foro,// kiñeke lelify,/ kafey ñi pülli deumay/ ina ngüyküllüfi ñi lipangmew./ / ülkantunge pienew ti lelfün/ pengenochy mapu ñi Úl/ ina pienew/ amunge doy ayeple wanglen." ("Llegun")

La pampa recogió uno a uno/y los recogió uno a uno/luego amasó mi espíritu/meciéndolo entre sus brazos.//La pampa me pidió que cantara / la poesía del infinito/luego me dijo que fuera / Hasta el gran fuego de las / estrellas. / Me dijo que allí despertaría" ("Creación").

- o como modo de expresión:

“...Umagtuken/lafken pewmamu ina nepeken/ challwa nepenmu./ Ayeken kÜmemew, / Ngümanken mawünmew / feley ta ñi mongen,/ feley ta ñi nütram, / fewla umagtuan." ("Mañkean ñi dungu")

"Mi risa es el sol del mediodía/mis lágrimas las vertientes,/mi dormir es el descanso del amor/y mi despertar la vida de los peces./ Es así mi existir/es así mi palabra/y las aguas me continúan cantando" ("El sueño de Mañkean").

- o como un aspecto esencial del "ser" mapuche, quebrado en su acontecer vital y cultural por el desarraigo:

“...Ñ̃i rakiduam amuñkeawi/kintupelu ñi longo enkellmew./ FÜchakeruka enkellmew/Ñi wün inaniefi ti dungu/lefi yengün wayunpüle / ina inche tüfamew mülen / kimnokechy" ("Wed-weden kiñe antü”).

“...Mi pensamiento vaga buscándome la / mente/ entre las paredes de edificios / iluminados y fríos. / Mi boca corres tras sus palabras / 
que huyen y yo me quedo aquí / sin nada, sin comprender" ("Confusión").

Este poemario también inscribe como motivos fundantes el motivo del "silencio", "la memoria" y "el testimonio", como recursos de respaldo de la oralidad frente al modelo escritural, y que los posteriores proyectos poéticos de Bernardo Colipán, César Millahueique y Jaime Huenún, reivindicarán y desarrollarán como discursos de la tradición cultural oral oponiéndolos a los mecanismos del discurso occidental escrito e impuesto. Se establece de este modo, un complejo sistema de recursos discursivos que buscan apoyar la superestructura discursiva como estrategia mayor, y cuyo objetivo es enmascarar el canon discursivo y estético occidental que le sirve de soporte expresivo, resolviendo con ello "adecuadamente" el conflicto de su opción por la escritura sobre la oralidad como condición primariamente vista como impuesta y luego también aceptada(Cfr. García, M. 2005c).

Entendiendo que una propuesta de retradicionalización de los cánones propios marca una identidad estética diferenciada al interior de la literatura nacional, Lienlaf continuará reforzando este concepto a través de sus posteriores publicaciones: Pewma dungu. Palabras soñadas (LOM, 2003) y Hierba_Agua (Ed. Propia, 2006).

Por otra parte, el libro En el país de la memoria de Elicura Chihuailaf -texto del cual solo se publicaron setenta y cinco ejemplares en su primera edición de 1988 y que reúne los poemas dispersos en revistas que circularon durante la década de los ochenta en el país- logra su articulación como conjunto al poner este autor en paralelo dos hitos históricos: "la pacificación de la Araucanía", aludiendo con ello al proceso de colonización del pueblo mapuche, y "la pacificación chilena", refiriéndose con ello al golpe de Estado de 1973.

Desde su título, este poemario inscribe no solo el proceso vivencial que transitan prácticamente todos los escritores y en general los artistas mapuches como experiencia de recuperación de la identidad étnico-cultural, sino que además contiene y es al mismo tiempo la metáfora fundante de una estética de la reconstrucción ontológica del ser cultural, como tal es la apertura entre el no querer ser lo que se "es" en la actual circunstancia histórica y aquél que se quiere recuperar. Un movimiento iterativo de este entremedio del sujeto enunciador que en cada texto y /o proyecto poético se ubica más cerca o más lejos de la positividad o la negación de un imaginario sobre la 
cultura tradicional o, desde otro punto de vista, del centro o la periferia de este ethos cultural.

Tal vez uno de los textos más decidores de este espacio de focalización, desde el cual el emisor textual contempla y evalúa los acontecimientos históricos, es justamente el poema "En el país de la memoria" que da nombre al libro:
"Retroceden ríos, piedras y los pájaros / remontan hacia abajo / Los canelos sagrados nos recuerdan oraciones / mientras las machis en los últimos bosques / se refugian/ No hay serpientes que eleven adormilados cerros / No hay estrellas, sólo la pálida luna / nos alum- bra y oculta en su otra cara los temores / La nutria del mar guarda silencio/ pues sabe que el invisible barco es / más fuerte que el acero / En el país de la memoria / somos los hijos de los hijos de los hijos / la herida que duele, la herida que se abre / la herida que san- gra hacia la tierra".

Un poema que se sostiene en el tópico del "viaje a la memoria"(Contreras, V. 1996), como viaje mnémico al mundo ancestral, búsqueda existencial personal y colectiva, ritualizada, que pretende develar su propio encuentro con los elementos primarios culturales.

Refiriéndonos a los mecanismos de transtextualidad descritos por Genette, este poemario se caracteriza por avanzar en la búsqueda de nuevas estrategias, todas ellas legitimadas por los proyectos posteriores. A partir del tópico del "viaje a la memoria" como procedimiento interdiscursivo y centro articulador -semántico y formal de la recuperación cultural- esta obra busca vincular el discurso occidental con el discurso mítico de la cultura tradicional, y coloca el discurso poético mapuche por primera vez en directa relación con el discurso histórico oficial, tal como se puede apreciar en el poema "Leufudungun" (El habla de los ríos), donde el texto base es intervenido tanto por el discurso de la crónica como por el discurso periodístico, no solo con la intención de convocar a la lectura plural sino con ello deconstruir la versión legitimada desde la escritura de tradición occidental.

Brillando mientras el dulce olor de los canelos

y laureles subía hacia los cielos

los padres de mis padres miraban la Cruz

del Sur 
límpida Cruz del Sur que no recordaba

espadas ni pólvora ni sífilis

límpida Cruz del Sur

no había entre nosotros torturados

ni desaparecidos

y la tierra y el aire eran la Libertad

Después nuestras madres

$$
\text { /lorarían }
$$

en medio de la guerra

Habían llegado hasta organizar jaurías de perros bravíos, los cuales, a una señal dada, avalanzábanse furiosamente contra los indígenas, destrozándolos horriblemente en unos cuantos minutos.

Después después nuestras hermanas

/lorarían

a sus asesinados y a sus desaparecidos

Verdaderos los escondidos ríos de la Historia vienen a mi encuentro. Sí, ebrio estoy probablemente ebrio: sobre el papel veo palabras signos colgando de la nada, necias palabras oigo en este aire que nos han cambiado

(negras campanas arden

en el aire norte/oeste

que nos dejan) 


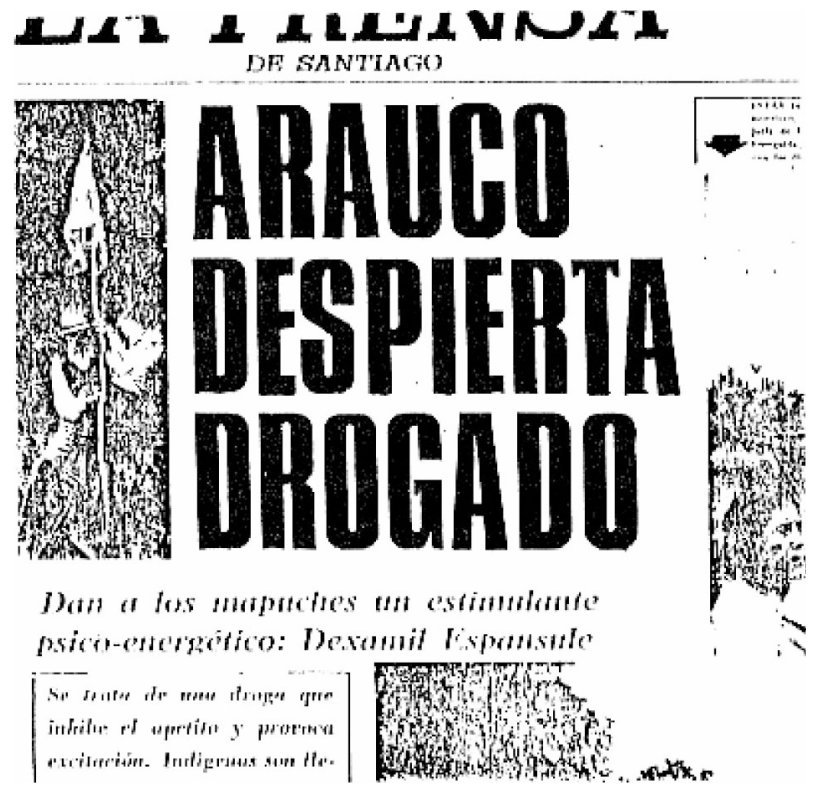

fueron muchas las mujeres que teniendo constituídos sus hogares con indígenas i a pesar de que éstos les concedían su libertad, no ANGANAMON I SUS AMORES CON LA quisieron abandonar las rucas en que vivían. INFORTUNADA MARIA DEL CASTILLO por sus hijos de padres araucanos i porque sentían vergüenza de regresar

fueron muchas las mujeres que teniendo constituidos sus hogares con indígenas i a pesar de que éstos les concedían su libertad, no quisieron abandonar las rucas en que vivían, por sus hijos de padres araucanos i porque sentían vergüenza de regresar"

Con una visión fuertemente crítica, luego de contextualizar en los primeros versos el decurso que ha tenido la relación intercultural e interétnica, este poema insiste en intersectar continuamente los acontecimientos de violentación de la cultura española y chilena-occidental sobre la mapuche, 
representando a través de diversos tipos discursivos cómo ha sido este diálogo en el pasado y cómo persiste en el presente.

Esta compleja estrategia escritural, en el caso de la inclusión del discurso de la crónica, por una parte no solo busca aludir a los contextos de enunciación originales en el pasado, sino también busca resemantizar el sentido del texto con fragmentos de otras versiones, provocando: un quiebre al verosímil del discurso histórico oficial, y/o simultáneamente una lectura de simetría-cultural ante el mismo acontecimiento, y/o problematizar lo registrado por la escritura y sus tipos de discursos -“... sobre el papel veo palabras / signos colgando de la nada, necias palabras oigo / en este aire que nos han cambiado..."

Si bien, por una parte se busca cierta fidelidad discursiva con la crónica, como es el caso de la Histórica Relación del Reino de Chile (1646), donde Alonso de Ovalle relata:

“y es tal la vergüenza y confusión que tienen, particularmente las mujeres cautivas, de verse en tal vil traje delante de los españoles, que tal vez he oído decir que se escondian de ellos, porque no las viesen, y no ha faltado quién ha rehusado salir de aquella desdicha, aun teniendo ocasión de poderlo hacer, sólo vergüenza por no parecer delante de los suyos y padecer la confusión de que las vean cargadas de hijos de los indios;..."(2003:374),

por otra parte, se busca también la confrontación de versiones con el fin de provocar su propia deslegitimación como argumento de la verdad histórica: así, mientras una de ésta opera a través de lo que explicita el discurso poético, donde Anganamón mantiene un supuesto amor con María del Castillo y se privilegia una interpretación positiva del contacto interétnico, otra lectura, más competente, alude inevitablemente al discurso del cronista Diego de Rosales en su Historia General del Reyno de Chile (1878), en el cual los acontecimientos en que participa Anganamón refieren a una relación forzada que desemboca en la traición de sus mujeres mapuches como también de la cautiva española.

Desde otro punto de vista, la inserción que este poema hace de otro discurso de la cultura occidental, específicamente del discurso periodístico, tiene como objetivo central anclar los acontecimientos pasados en el presente y con ello dar cuenta de que la relación cultural asimétrica persiste en el tiempo. Con este fin se buscan los recursos de exageración e inversión de los significados, los que actúan simultáneamente a diferentes niveles 
interpretativos, operando el primero mediante una hipérbole -significado, imagen y tamaño de la tipografía- que redunda en acrecentar la impronta habitual y negativa que la cultura chilena-occidental ha difundido sobre el pueblo mapuche; mientras el segundo, la inversión, busca someter este significado a los nuevos nexos que el discurso noticioso establece con el sentido textual total, originándose un sistema de contralecturas éticas que hace ver un sujeto imputable de violencia en los acontecimientos históricos, en los cuales la víctima ha sido y es el pueblo mapuche.

3.- Las propuestas actuales: territorializar la diferencia. Transcurrida una década -entre esta etapa fundante y referencial para la actual generación poética- los borradores que se trabajaban desde mediados de los noventa toman cuerpo en la edición y publicación de varios libros reforzando este ámbito dialógico. Cabe destacar en relación con este procedimiento algunos textos representativos de esta última etapa, entre ellos Oratorio al Señor de Pucatrihue (2004) de César Millahueique; Mapurbe. Venganza a raíz (2005) de David Aniñir y Arco de Interrogaciones (2006) de Bernardo Colipán.

Oratorio al Señor de Pucatrihue, el segundo libro de César Millahueique, es un poemario de orientación narrativa que despliega su trama en veintún sueños, donde el primero ("Kiñe") y el último ("Epu kiñe”) permiten el traspaso de un sujeto desarraigado culturalmente desde las "aristas del infierno" - la urbanidad- a la experiencia comunitaria de la cultura tradicional; sentido que este autor intersecta, en tanto contradiálogo de los espacios sacralizados -cultura mapuche/sociedad occidental- con su primer poemario Profecía en blanco y negro o las 125 líneas de un vuelo (1998).

Desde el punto de vista de la afirmación de lo propio, Oratorio es la búsqueda y encuentro con los saberes primigenios de la cultura williche como práctica cultural y es, simultáneamente, denuncia del despojo y de la intervención histórica; mientras, desde el punto de vista de la recuperación de los códigos culturales ancestrales es la exploración por el logos del lenguaje y su límite o permeabilidad cultural, al someter a prueba en el mismo espacio textual discursos culturales propios y ajenos, como el discurso poético, el canto sagrado y ritual (oratorio), y el discurso del pewma; una imbricación que pone en crisis la superestructura del discurso poético, como instancia representativa del cánon occidental.

Si el "oratorio" adquiere la función de nexo espiritual en el acto de comunión con Wenteyao -divinidad huilliche- 
“... escucha la/ canción la oración viaja por los ríos./ / Señor de Pucatrihue danos la lluvia danos el color de la/cereza. Besa el corazón de la manzana acepta el cordero/ harina tostada la mirada de tus hijos./ / Señor de las rocas háblame en el sueño ilumina la noche del territorio..."

(Epu), el "pewma" como medio de comunicación intracultural permite territorializar el espacio de la enunciación desde los códigos propios y desvincular al sujeto textual del espacio de lo ajeno para sumergirlo en el espacio ritualizado (Cfr. García, M. 2004, 2005d, 2006).

"El mundo circula afiebrado por las aristas del infierno.

Una muchacha dibuja el misterio de los pájaros;

Se sienta desnuda en lo alto de la noche.

Los pájaros siguen sobre los sueños, estoy afiebrado, vuelo con ellos.

Estoy en harapos corro hacia el territorio.

Hoy llueve igual que en los sueños; la tierra húmeda me vuelve loco.

La lluvia cae, humedece los sueños. Ahora un puma ruge entre la lluvia.

En otro sueño, el olor a leña se enreda en el fuego.

¿Quién puede escapar de este lugar?

Cabalgo...me pierdo en la profundidad de la lluvia...." (“Kiñe”)

Pleno de imágenes, símbolos y metáforas, el pewma aquí se constituye narración y comunicación cultural, y potencia el registro documental como imagen panóptica de este viaje; así el pewma es sobre todo el lenguaje que permite la aproximación con los suyos para encontrar sentido a la vida:

"Mira $\quad-$ me dijo- $\quad$ anoche he soñado contigo

corrías por sobre esos árboles allá al fondo de mi casa corrías con una sonrisa en los labios

herido en el pecho... los bandidos te habían disparado (...).

-¿Dónde vives? -le pregunté.

-por sobre esos árboles está el mar -me dijo.

-¿Dónde está tu casa? -le pregunté.

-Por esos lares... donde se esconde la luna -respondió.

¿¿Hacia dónde caminas? 
-Donde desembocan todos los ríos -me dijo.

-¿Y dónde están tus hijos?

-Bajo todas las lluvias respondió.

-¿Y tu mujer...? ¿Dónde está tu mujer?

-Descalza por Avenida República -me dijo-

lleva una vela prendida a contra viento

por la luz la reconocerás

iluminando la memoria muchacho...

iluminando la memoria.

Ya basta $\quad-$ me dijo- no llores más sigue esa luz

no temas, anda vete los ecos del terror ya no te atormentarán

ve a contraviento a contraviento wiyiche...

$-y$ se fue al fondo de los hualves-(...)" (Epu Kiñe)

El pewma, en tanto estado visionario, ha subsumido al discurso poético como canon, desplazándolo sin tensión al devenir pleno acontecimiento, permitiendo en este transcurso que cobren vida otros tipos discursivos que integran el poemario: el discurso poético -en verso y en prosa poética-, la conversación, la arenga, la oración ritual, el discurso testimonial.

Este discurso, desde el punto de vista intratextual, como dispositivo cultural totalizador y fundante de una realidad múltiple y especular, integra en su despliegue la representación de su misma actividad -la instancia de la práctica cultural donde la conversación entre soñador e intérprete busca descifrar el mensaje de este código; sin embargo, desde el punto de vista transtextual, el pewma como superestructura solo puede ser visto como acontecimiento, la plena ocurrencia como vivencia y estadio anterior a la interpretación del sentido global.

El pewma, como lenguaje cultural y despliegue del "am" (alma) en este nuevo estadio, que coloca al presente histórico entre paréntesis, es el anverso del tercer poemario de Millahueique: Imágenes del Rito (2006), donde bajo la misma estrategia, los sueños, ahora proponiéndose como forma de percepción del discurso occidental, son descripciones narrativas, próximas al relato, de un acontecer fragmentado, donde el sujeto textual observa su propio tránsito, desdoblado en una tercera persona, en el espacio de la ajenidad.

"Eran osamentas en esos acantilados, cayéndose hacia el fondo de los riscos, hacia la espesura de esos mares, de esos cuerpos 
con el vientre rajado, navegando anónimos frente a las playas, siendo la cicatriz de esas costas.

El fantasma de aquellos años le siguió, a esa altura le susurra palabras familiares al oído, en el umbral de la noche se abrazan borrachos y cantan.

Todo fue demasiado cruel, demasiado duro, por ello se ha pasado caminando en esta noche de ladridos lejanos y sin gallos que canten en la próxima mañana...” (“Tres")

Este juego discursivo e intertextual entre los tres textos de Millahueique son la entrada y salida constante de un intradiálogo con los lenguajes propios y los ajenos, con su propio mestizaje y con su identidad. Sin embargo, también son la evidencia de una posición y significado cultural que se quiere simbolizar con el desplazamiento y/o imbricación de estos cánones discursivos.

Se establece aquí un proyecto escritural que abre los espacios textuales para significar oposiciones formales y semánticas, a través de las cuales se busca dar cuenta de la vivencia cultural de un sujeto puesto en condiciones históricas adversas, lugar desde el cual se enfatiza por mostrar un registro cultural diferenciado: en el ámbito de la religiosidad -Profecía (apocalíptica) / Oratorio-; en los lenguajes -Pewma/Imágenes-; en los espacios comunitarios -sacralización/reificación-; en los espacios institucionalizados ruralidad/urbanidad-; en los espacios culturales -lo propio/lo ajeno-; y en los espacios de la reflexión -la memoria/la cotidianeidad.

Otro ejemplo de cómo se busca representar la dinámica del dialogismo discursivo, intra e intercultural, es el texto Mapurbe. Venganza a raíz (2004), de David Aniñir. Un poemario que replantea la situación del desarraigo del mapuche en la marginalidad sociocultural urbana, inscribiendo su sentido crítico en la nueva etapa del movimiento artístico mapuche, en la cual los textos, tanto en su orientación política como en la representación que hacen de experiencias urbanas más complejas, se instalan frente al discurso de la globalización, reorientando la actitud de la resistencia cultural ya no solo hacia la hegemónica sociedad chilena, sino además hacia "la madre más puta": el colonialismo capitalista.

Este libro, a través de integrar los lenguajes del rito, el mapudungun junto al castellano, una focalización y conceptualización específica sobre quién es el mapuche urbano -a través de proponer la noción de "mapurbe"-, la 
evocación dialógica con versos de Elicura Chihuailaf, Nicanor Parra, Pablo Neruda, letras de las canciones de los 'Fiscales ad-hok', a modo de epígrafe, entre otros procedimientos que se sostienen en la transtextualidad, busca como procedimiento articulador del significado y del sentido textual el discurso del "Yeyipun", como un conjuro para compensar el estado de precariedad y de desequilibrio del ser mapuche en la situación de desarraigo.

Este discurso, que forma parte del rito de renovación de las fuerzas espirituales (Wetxipantu: año nuevo mapuche),tiene como función invocar "la intermediación de los ancestros sagrados para que el dueño de la gente y el cosmos "Gnemapun, Elchen, Elmapun o Gnechen restablezcan la comunicación espiritual”(Manquenahuel, J. P. s/f). En este sentido, el discurso del "Yeyipun" es instaurado como espacio articulador de protección, desde el cual el emisor textual se desplaza para reflexionar y evaluar su ajenidad, y desde el cual busca refugio para su exilio cultural.

Frente a esta fórmula de comunión con la cultura ancestral se instala la transculturación que separa o altera las dimensiones fundamentales del "che" o persona mapuche: donde el "alhue" (cuerpo inerte), el "am"(la imagen) y el "püllü"(espíritu o vida) son sometidos a continuas tensiones y disgregaciones debido al proceso de angustia que descentra al ser. Así, Mapurbe construye el espacio para visibilizar el anverso del ethos tradicional, donde el "yo soy" es el "indio" desarticulado, desarraigado y despojado de su ser cultural (tierra-territorio, comunidad cultural), constituyendo un sujeto agónico, que lucha por recuperar y sostener su identidad cultural:

"Soy el indio de la selva gris / Poetizando el eructo flateado de tintos / En fiestas de silencio / esparciendo vómitos / A lo alcantarillado de los cráneos inertes" (ACULLÁ Nieva pus)

En Mapurbe, los textos referenciales son los textos culturales: el colonialismo, la historia oficial, la escrita por el colonizador: "Las mentiras

6 "Marri-marri wenu kvze/ Marri-marri wenu fvcha/ Marri-marri ulcha domo/ Marrimarri weche/ Marri-marri newen ñuke mapu/ Marri-marri kuifi keche mapuche/ Marrimarri kom pu che mapurbe. / / Marri marri kvyem wanglen kom newen wenumapu / allkutuaiñ taiñ dugu/allkutuaiñ taiñ pvlyv/ allkutuaiñ taiñ rakiduam/ Memoria pú lonko, Pu machi, $\mathrm{Pu}$ weichafe, $\mathrm{Pu}$ werken/ kom fvcha keche, petu mongeley//. 
acuchillaron los papeles / se infectaron las heridas de la historia" (María Juana la Mapunky de La Pintana).

Este poemario conduce a la lectura del aquí -el hoy, el desarraigo, el desequilibrio, la tristeza, la marginalidad-, y de un allá -el mundo antiguo, la pureza, el tiempo anterior; entre el aquí y el allá se extiende el "Yeyipun" como hilo conductor hacia los demás poemas, abriendo el espacio a un sujeto textual que actúa como "werkén", el mensajero, "Aqui solo soy un traficante de sicotrópicas lineas/Soy el werkén de tus pewmas" (E1 Pewma del Mundo Trasero) -reiterando de otro modo la noción antes comentada, del poeta de Elicura Chihuailaf-, instalándose en un espacio otro, en una realidad otra, en la cual aspira a "creer que cree en el mundo" que es lejanía y posibilidad.

Mapurbe es un texto orientado a mostrar de la vida del mapuche en la urbe: la mapurbe:

"Somos mapuche de hormigón / Debajo del asfalto duerme nuestra madre / Explotada por un cabrón./ / Nacimos en la mierdópolis por culpa del buitre cantor/ Nacimos en panaderías para que nos coma la maldición / / Somos hijos de lavanderas, panaderos, feriantes y ambulantes / Somos de los que quedamos en pocas partes / / El mercado de la mano de obra/ Obra nuestras vidas / Y nos cobra / / Madre, vieja mapuche, exiliada de la historia / Hija de mi pueblo amable / Desde el sur llegaste a parirnos / Un circuito eléctrico rajó tu vientre / Y así nacimos gritándoles a los miserables / Marri chi weu!!!! / En lenguaje lactante..." ("Mapurbe")

En contraposición a este espacio de violentación, la rearticulación del sujeto solo ocurre en relación con la cultura tradicional, el lugar del reencuentro:

"Ser tú es la evolución misma/ Estar en ti significa asfixiarme de sueños / padecer en la tortura y no diluirme en tu ensueño / Donde tú construyes esfinges y cántaros prehistóricos/ Ahí donde la serpiente jugaba contigo en vida / Ser tú es estar en ti / Es quererme a mí mismo pues, tú estás en mí/ Y es lo mismo...” (El Pewma del Mundo Trasero)

En el lado opuesto al espacio cedido por el "Yeyipun" se busca ironizar el "Salmo" como discurso de la tradición judeo-cristiana y referente 
occidental", acotando con el poema "Salmo 1997" un sentido de la oración y del compromiso cristiano desrealizado, al invertir a la manera de Parra lo sacro por una anti-ética del proceder deshumanizante que mantiene la cultura occidental:

"Padre nuestro que estás en el suelo/ Putificado sea tu nombre/ Vénganos de los que viven en los faldeos de La Reina/Y de Las Condes / Hágase señor tu unánime voluntad / Así como lo hacen los fascistas en la tierra / -nuestra tierra- / Y los pacos en la comisaría / Danos hoy nuestro pan que nos quitan día a día / Perdona nuestras verdades / Así como nosotros condenamos / A quien no las entiende. / No nos dejes caer en esta invasión / Y más líbranos del explotador..." ("Salmo 1997”).

Mapurbe es un texto dialógico donde el sujeto textual habla hacia la cultura propia, y desde allí también a los otros poetas mapuches, sobre todo haciendo referencia a Elicura Chihuailaf, a través de su concepto de "oralitor", y de quien también cita el verso "Somos los hijos de los hijos de los hijos", aludiendo al poema "En el país de la memoria":

"Somos los hijos de los hijos de los hijos/ Somos los nietos de Lautaro tomando la micro / Para servirle a los ricos / Somos parientes del sol y del trueno/ Lloviendo sobre la tierra apuñalada..." (Mapurbe).

Este poemario es también el acto de conciencia de quien busca registrar la historia, y como tal se transforma en evidencia la paradoja que transitan actualmente los movimientos de resistencia cultural, sobre todo los pueblos originarios, al afirmar en uno de los principales elementos de la intervención cultural: la escritura, el proceso de decantamiento de su experiencia de hegemonización cultural, por una parte, y por otra, el reencantamiento por su cultura ancestral, desplegando así en el mismo espacio escritural tanto la evocación de los elementos culturales tradicionales e inscripción de prácticas rituales de la cultura oral, como la actitud de denuncia y la posición de resistencia cultural ante los elementos culturales homogeneizantes:

${ }^{7}$ Cfr. el mismo procedimiento en el "Salmo 1492" de Graciela Huinao (Walinto. La garza morena: 2001). 
"Corre el tiempo / Un reloj se esconde en el fondo de mi cuerpo / Corre el tiempo / Y la aventura de escribir la historia / Trae tierra semilla y raíz mi memoria / con el zumbido del viento / que corre friolento por las tablas de un templo de bosques. / Corre el viento con furia de venganza / Corre el tiempo entre los árboles escribiendo historias / De muertos reaparecidos..." (“Corre el Tiempo").

Un tercer texto que busca significar lo propio, desde las posibilidades epistemológicas que presenta el discurso artístico como instancia de reflexión de la relación intercultural y como medio de conocimiento de la propia realidad cultural de su pueblo, es el libro Arco de Interrogaciones (2005) de Bernardo Colipán.

Este autor propone, a través de su proyecto poético, interpelar a la poesía latinoamericana y chilena mediante un discurso que se dinamiza justamente por el encuentro discursivo de los cánones propios y ajenos; una estrategia que opera en el espacio textual mediante desplazamientos e imbricaciones de heterogéneos discursos, al modo de los rizomas deleuzianos, y que adquieren sentido a partir de una concepción del lenguaje como medio de control cultural.

Se debaten territorializando en sus orígenes y diferencias culturales los discursos del silencio, de la memoria, de la oralidad y del registro escritural, como vivencias y versiones de un mismo acontecimiento: la cultura mapuche-huilliche y el encuentro e intervención cultural. Reiterando la misma estrategia que se ha visto en los proyectos anteriores, este escritor articula el poemario a través de un nexo transversal que resuelve su posible tensión discursiva: el discurso del nguillatún, la oración ritual tradicional que convoca a Ngenechen, padre de la justicia y proveedor de alimentos, a hombres y mujeres, a la madre luna y el padre sol, al ejército encantado de Pucatrihue, al intercesor entre los hombres: Taita Wenteyao, y a la madre tierra.

"Lefketumay Chao Dios/ Lefketumay Chao Trokin/ Lefketumay Treng-Kawin/Lefketumay Pu lamuen-Wuentru/ Lefketumey Ñuke Ale/ Lefketumay Chao Antu/ Lefketumay Pukatrihuekeche/ Lefketumay Aguelito Wenteyao/ Lefketumay Ñuke Túe".

Este discurso, encargado de abrir y cerrar el conjunto poético, es propuesto como eje articulador del tiempo y espacio en que deben ser interpretados los acontecimientos, los sujetos y las vivencias, circunscribiendo la 
plural remisión de los discursos a esta plena circularidad, donde todo posible significado es intervenido por este sentido cultural esencial de la cultura tradicional.

El discurso ritual abre el espacio textual a lo sacralizado, transformando así toda acción individual en colectiva; es, por lo tanto, en sí mismo el acontecimiento, la voz y el significado cultural que se hilvana desde la pluralidad de puntos de vista; él "es" los modos de existencias anteriores y presentes, lo nouménico y lo humano, la trascendencia y la contingencia, la totalidad del territorio del ser cultural; y cuya función como discurso en la textualidad es el esfuerzo por la traducción de lo inefable a través de instaurarse como pleno acontecimiento, es también simultáneamente explicación del despliegue del ethos cultural en su presente histórico-ahistórico y deseo de comprensión y entendimiento de sí, individual y colectivo, de la vivencia cultural.

El proyecto poético es el ingreso a 11 secciones y 13 "arcos" -los que pueden ser asociados a las 13 lunas o fases lunares de la cultura- en cuyo espacio simbólico, contenido por la oración ritual, tiene lugar la secuencia de textos que narran la experiencia cultural:

"Las bandurrias vuelan en bandada./ Bajo las piedras algunos insectos / corren perseguidos por otros./ harina tostada y muday/ ardiendo en el fuego sagrado./ De rodillas esperamos la salida del sol. / Con el rocío las oraciones ascienden / hacia la "Tierra de Arriba"./ La tierra vuelve a ser jardín/ poblado por antiguos pasos/ Una página en blanco / una vasija / en donde cabe todo / un puñado de semillas en un instante./ El fin de mi aliento es/ el comienzo de otro/ Nuevamente la palabra traduce/La reunión de las cosas" (“Arco de nguillatún”).

Como en "Viaje a la semilla" de Carpentier o "Cien años de soledad" de García Márquez, este texto poético inscribe "palabras de poder", mediante las cuales el mundo vuelve a lo primigenio, reconstituyéndose desde la nada, porque en este sentido el acontecimiento mismo es "la palabra" como referente esencial; después, el despliegue de los discursos testimoniales que prueban la existencia de una cultura ancestral viva, y a partir de ellos, la traducción y resignificación poética que busca simbolizar la conservación de la tradición en la generación vigente: 
"Yo tendría ocho años. Era un día de cosecha. Se estaba cosechando adonde están ahora los Llanquileos, al otro lado donde vivíamos nosotros.

Allá todos se juntaban en una sola parte, el día que se formó el eclipse, como le dicen ahora: eclipse de sol.

O sea que toda la gente se asustaba en ese tiempo....

En esos tiempos mi abuelita era bien anciana.

Entonces, ellos se juntaban entre hartos vecinos que estaban más cerca y ponían una fuente con agua para mirar el sol, porque para arriba uno no puede mirar el sol cuando está el eclipse, porque chispea mucho y ahí lo miraban en la fuente. Rezaban y ahí miraban el sol"

("María Elvira Piniao, Pulotre, San Juan de la Costa").

"Fue un día de cosecha, allá donde los Llanquileos./ Nos juntamos nosotros los huilliches / y el sol. / Yo tendría todo el temor alojándose / en lo húmedo del pulmón izquierdo. / Asistimos a la muerte del sol./ Lo velamos en cuerpo presente./ Rezamos mucho./ Rezamos y vimos su rostro/ reflejado en la fuente/ con agua./ Antu kushe, Antu fucha wentru./ Tres veces nos arrodillamos/y el canto/ no cayó en el vacío..." ("Lan Antu").

Enfatizando la recuperación por la fundación del mundo y en la búsqueda de visibilizar un nuevo orden, este proyecto busca deconstruir la noción de la historia como progreso; en este contexto, el proceso probatorio y contra-argumentativo del discurso centra su focalización en la práctica ritual ancestral, ante la cual el emisor textual, asumiendo primero la posición de espectador, del observador que registra, es progresivamente subsumido por la atmósfera religiosa, identificándose con el acontecimiento; este es el camino a argumentar el sentido y la conexión de lo divino en lo humano, oponiendo al discurso histórico un discurso meta-histórico, una reflexión sobre el origen y el devenir de la cultura.

"Anochece. Una mano dibuja en los vidrios/ el rostro de una helada, cuyo nombre ha olvidado./ Los manzanos sueñan la felicidad/ de compartir el mundo con los pájaros./ La Nueva salida del Sol ilumina/ el camino de los perdidos./ El invierno hunde sus pies/ dejando una huella sin forma./ La estación de las lluvias es nuestro único consuelo./ Noche de Wetripantu. Un nuevo orden perdura en las cosas./ La memoria recupera el silencio/ anterior a la palabra" ("Noche de wetripantu"). 
El cruce discursivo -ritual, mítico, historiográfico, testimonial, de la crónica periodística, de la memoria y del silencio, del discurso poético- en el discurso poético, refieren al objetivo palimpséstico y especular de este texto como el lugar donde se busca contemplar la mismidad; una obra poética que desde otro punto de vista conjuga en el espacio textual relato y poesía, oralidad y escritura, historia y mito, acontecimiento e inscripción, donde se busca plasmar la constitución ontológica del ser cultural, y soportar en ello el movimiento epistemológico desde el espacio del juego del lenguaje y su doblez, tanto en la dimensión de participante y observador; ironizando con ello el lenguaje como posibilidad comprensiva de los acontecimientos, en cuya evaluación, deja al descubierto que todo discurso como así también el discurso poético es el lenguaje puesto en práctica, y aún en esta condición es sólo la aproximación mediada al ethos cultural, al que busca hacer visible (cfr.García, M. 2005b).

\section{ENTRE-TEXTOS II: METAPOÉTICAS O UNA ESTÉTICA DEL ETHOS CULTURAL}

La transtextualidad como procedimiento discursivo que colabora a la construcción de un metadiscurso sobre el arte y la poesía -mediante la cita en textos, la alusión explícita y/o metafórica de ésta en la dedicatoria, epígrafe y/o en títulos, la inclusión de ciertos versos que actúan como correlatos, entre otros-, en el caso del discurso poético mapuche no establece una característica propia o diferencia radical con lo que ha sido tradicionalmente su empleo en la poesía universal; sin embargo, respecto de los dispositivos dialógicos que tratamos en este estudio, resulta relevante interrogarse cómo, a través de los procedimientos transtextuales, estos proyectos resignifican las premisas estéticas del discurso poético occidental, con el objetivo de fundamentar una metapoética vinculada con una identidad cultural propia.

En esta misma dirección, cabe reflexionar si este discurso metapoético forma parte de una construcción argumentativa mayor con que los proyectos artísticos mapuches buscan visibilizar al arte y a la poesía en términos de una propuesta de autonomía estético-cultural, debido sobre todo a que este metadiscurso traduce una posición enunciativa y de direccionalidad del texto y del proyecto poético respecto del sistema literario en que se introduce. 
En esta perspectiva, cobran especial relevancia las propuestas que realizan dos de los proyectos poéticos más reconocidos por la crítica nacional; me refiero con ello a la obra de Elicura Chihuailaf Nahuelpán y de Jaime Huenún Villa.

En el primer caso, aludiendo al proyecto poético de Elicura Chihuailaf, podemos establecer que éste puede ser comprendido como una instancia de articulaciones dialógicas transversales, posibles de ser revisadas en relación a un discurso que busca fortalecer la visibilización y evaluación de los acontecimientos histórico-políticos entre el pueblo mapuche y la sociedad chilena, fundamentar una posición estética sobre la poesía mapuche a partir de examinar un concepto de "palabra" inscrita en los elementos culturales propios, y concebir el texto como un espacio de comunicación intercultural en tanto apertura de encuentro e interacción.

En este mismo sentido, y especificando que estos tres ámbitos se interrelacionan al interior del espacio textual al formar parte de un mismo proceso, la resistencia cultural, este autor inscribe desde el inicio de su proyecto escritural los primeros trazos sobre una perspectiva propia de qué es la "poesía", noción que va caracterizando progresivamente a partir de un conjunto de cuatro textos que se despliegan a lo largo del libro En el país de la memoria (1988).

"Poesía", el poema que abre este libro, es un texto que simboliza en sí mismo el presente histórico en tanto contingencia, la recomposición de un sujeto textual impactado por la intensidad de los acontecimientos -metáforas de la represión política y cultural-, y una perspectiva sobre el sentido del arte como recuperación humanizada del mundo, configurándose así un texto poético como espacialización de un estado de existencia en el cual se debate el proyecto del "ser" que, suspendido ante esta realidad, resuelve por una razón de existencia en el "hacer": "Poesía".

"¿Qué hacer, ahora que los días pasan / sin reloj ni calendario / cuando no se pueden segar los sueños/sembrados por el viento/ ni se puede alegrar a un niño/ con bolsas de pastillas? /¿Qué hacer, ahora que ya no se cree/ ni en la inocencia de la nieve/ (en su carroza silenciosa)/ y tan pocos creen/ que es un ave blanca, gigantesca/ desplumándose o desplomándose/ sobre la madrugada?”.

"Poesía", como la única respuesta y acción posible ante un mundo desvastado, es en sí la posibilidad de realización ante aquello ausente: la 
vida, los sueños, la alegría y la esperanza, sintetizando el anverso del dolor, la inercia y el no-sentido.

A partir del dar cuenta de esta perspectiva desoladora sobre la "realidad" y su resolución y resignificación mediante la creación poética -e iniciar con los sucesivos textos el tópico del "viaje a la memoria"-, este autor se detiene en fundamentar cuáles son las vinculaciones y razones que tiene este "hacer" en su propia cultura. En esta dirección, la actividad poética es concebida como ofrenda e instancia de conectividad con los antepasados:

"En las manos ahuecadas de antiguas gentes/ deposito mis versos sin telón ni luminarias // porque no son aventura impensada de tardes / lúgubres// y porque arrastran su carreta filial/ por los caminos" ("Gente de la tierra");

$\mathrm{y}$, como un medio de denuncia y de recuperación de lo propio que se articula a partir de una concepción de la "palabra" como representación de la expresión cultural:

"Madre/ yo sé que no es retórica tu llanto/ tras las ovejas perdidas / Yo sé que no es retórica / ni pose ni risa / tus dientes blancos en la portada/de aquel folleto/propaganda de una agencia de viajes/ ni lamento/ El nuevo mundo se cierne/ sobre nuestras cabezas / Madre, es oscura la noche/ y es tanta la lluvia/ en este invierno maldito / que me dan ganas de volver y desafiar/ la más desafiante soledad/ de una página en blanco/ sin el más mínimo temor/ de llenarla con palabras sencillas/y gastadas como tus manos..."("Tras las ovejas perdidas").

Cerrando el poemario, se ubica estratégicamente el cuarto texto: "Las palabras"; poema breve que destaca la actividad poética como testimonio y registro de los acontecimientos histórico-políticos y culturales, y en el cual se releva una actitud profética sobre "la palabra" como el medio de resistencia a los acontecimientos, una instancia de reacción ante el estado de violencia cotidiana:

"Mis palabras se repetirán y se repartirán/ como la muerte en las ciudades / / (Guardaré por ellas un instante de silencio / a riesgo de quedarme mudo para siempre)". 
Sin embargo, será en su libro El invierno y su imagen y otros poemas azules (1991), a través del poema "La llave que nadie ha perdido" -que incluye también en De sueños azules y contrasueños (2000)- donde este poeta establecerá una concepción más acabada sobre este tema, al contraargumentar ante el sentido que la metáfora de la "llave" ha tenido y tiene en la estética occidental. Así, su referente más inmediato será el texto "El paso del retorno" de Vicente Huidobro, un extenso poema que refiere al viaje por la soledad, la nomadía y la extrañeza, de un sujeto que descubre en la poesía su compañera y en "las palabras poéticas" la posibilidad de dominio y control sobre un mundo nuevo, y la clave del saber consciente:

“...Es este que está llorando el universo

Que sobrepasó la muerte y el rumor de la selva secreta

Soy impalpable ahora como ciertas semillas

Que el viento mismo que las lleva no las siente

Oh Poesía nuestro reino empieza

Este es aquel que durmió muchas veces

Allí donde hay que estar alerta

Donde las rocas prohíben la palabra

Allí donde se confunde la muerte con el canto del mar

Ahora vengo a saber que fui a buscar las llaves

He aquí las llaves

¿Quién las había perdido?

¿Cuánto tiempo ha que se perdieron?

Nadie encontró las llaves perdidas en el tiempo y en las brumas ¡Cuántos siglos perdidas!...” (Vicente Huidobro)

Ante estas imágenes, el texto de Chihuailaf, al interperlar al de Huidobro, busca afirmar su propio concepto sobre esta metáfora, iniciando una serie de procesos de inversión que resignifican este primer sentido; de este modo se invierte la figura del desamparo del sujeto huidobriano por la figura del amparo cultural, donde el sujeto se ancla en el mundo, respaldado por una tradición cultural ancestral; contrapone a la aspiración fundacional de la poética centrada en el sujeto individual -simbolizada en el encuentro de las llaves perdidas- una poética del legado cultural -simbolizada en la cotidianidad de los acontecimientos:"nadie encontrará la llave que nadie ha perdido"-, y remplaza la función egotista de la palabra poética occidental por la función solidaria y comunitaria de ésta: 
"La poesía no sirve para nada, me dicen / Y en el bosque los árboles se acarician / con sus raíces azules y agitan sus ramas / el aire, saludando con pájaros la Cruz del Sur/ La poesía es el hondo susurro de los asesinados / el rumor de hojas en el otoño, la tristeza / por el muchacho que conserva la lengua/ pero ha perdido el alma/ La poesía, la poesía, es un gesto, el paisaje / tus ojos y mis ojos muchacha, oídos corazón/ la misma música. Y no digo más, porque / nadie encontrará la llave que nadie ha perdido / Y poesía es el canto de mis antepasados / el día de invierno que arde y apaga / esta melancolía tan personal" (Elicura Chihuailaf) ${ }^{8}$.

En esta misma orientación, su texto surge como respuesta al "Arte Poética” de Huidobro, oponiendo al concepto creacionista de poesía: "Que el verso sea como una llave / que abra mil puertas. / Una hoja cae; algo pasa volando; / cuanto miren los ojos creado sea, / y el alma del oyente quede temblando..." la del legado cultural:

“...Hablo de la memoria de mi niñez y no de una / sociedad idílica/ Allí, me parece, aprendí lo que era la poesía / las grandezas de la vida cotidiana, pero sobre todo / sus detalles / el destello del fuego, de los ojos, de las manos..." ("Sueño azul". De sueños azules y contrasueños, 1995).

Complementando lo anterior, cabe señalar que esta reflexión metapoética la ha desarrollado en diversos artículos, estableciéndose como referente central "Mongeley mapu ñi püllü chew ñi llewmuyiñ" (1992), texto donde propone conceptualizar la literatura mapuche como "oralitura", inclinándose con ello a un argumento contextual y cultural que le permite establecer "la cosmovisión" como hilo conductor de la creación artística, señalando que es ella "la que permite hablar desde y con los antepasados, pues contiene sus símbolos, sueños y gestualidad", lugar donde el texto reconoce y se reconoce en su tradición literaria. Por cierto que esta es una reflexión en la que el énfasis está puesto en los modos de transmisión cultural, dejando con estos argumentos abierto el camino literario también para los registros de la cultura tradicional ${ }^{9}$.

${ }^{8}$ En ambos textos el subrayado es mío.

${ }^{9}$ Cfr. el estudio que Sonia Montecinos realiza sobre este proceso ese mismo año en "Literatura mapuche: oralidad y escritura", Simpson 7, Revista de la Sociedad de Escritores de Chile. Vol. II, Segundo semestre, Santiago, Chile, pp. 155-166. 
De esta manera, el proyecto de Chihuailaf integra una perspectiva sobre la poesía, la palabra y la literatura como un ámbito compartido, donde su acceso es la posibilidad de toda la comunidad cultural, lugar donde también reside el poeta; así, el lenguaje como actividad poética y cultural es ancestral y se encuentra fundado en esta memoria cultural, permitiendo, por una parte, el reencuentro con la cultura ancestral, y, por otra, colaborando al proceso de resistencia cultural.

Desde el segundo proyecto que nos ocupa en este apartado, la construcción de un discurso metapoético propio en la obra poética de Jaime Huenún alude a un tránsito más complejo, vinculado con su propio proceso de mestizaje, y que se inicia en el texto inédito Al anverso carnal de las estrellas $(1994)^{10}$, particularmente a través de sus discursos iniciales: "A modo de presentación, explico algunas cosas" y "Portada".

Mientras "A modo de presentación..." habla sobre los orígenes de este poemario, la relación dialógica y conflictiva de su autor con lo indígena y de la tradición literaria - "la rama vallejiana y mistraliana"- a la cual se adscribe; surge en él un esbozo sobre la actividad poética como "Envío", aludiendo con ello a la actividad escritural como el fluir o tránsito hacia un "otro", y de la "poesía" como el estado activo que impulsa y dirige su camino hacia la cultura tradicional:

"Huilliche hispanohablante como soy, nacido y criado en los ámbitos de la sociedad chilena (occidental), perdida ya la inocencia de la raza y de la infancia, he debido agarrar la rama vallejiana y mistraliana para cobijarme bajo el árbol de mi origen. La poesía, esta desesperada paciencia, no duda en empujarme hacia los bosques y los ríos del tsé dungún (el perdido dialecto huilliche, variante del mapudungún, lengua de los hombres de la tierra)...”

No obstante, es en "Portada" donde se centra en debatir qué entiende por "poesía", asomándose ésta desde una visión sacralizada del mundo y desde el prisma del lado negativo de las cosas; un lugar donde la palabra poética se plantea como un posible "conjuro y talismán" - palabras de poder- y que, sin embargo, como tales no llegan a revertir completamente lo funesto o aciago de la existencia, dando cuenta del sentido conflictivo que

${ }^{10}$ Huenún, Jaime. Al anverso carnal de las estrellas. Texto inédito, 1994 (Borrador personal entregado por el autor). 
tiene la palabra -como actividad y escritura- en tanto imposibilidad de transformar la "realidad" y representar la esencia de lo nombrado:

"Sí, hablamos de poesía, decimos poesía como conjuro y talismán.
¿Conjuro contra qué, amuleto para qué la poesía? Contra los male-
ficios del amor, contra la tumba viva que somos, contra y a favor de
los huesos y la carne. Cierto es que no morirá la rosa, pero verdad
es también que ya nunca una elegía de sangre la tornará al esplen-
dor y al aroma

...Plebeyos del lenguaje, parias de la rima, nunca alcanzaremos el ritmo de un río ni la cadencia de los oleajes.

Decir esto es poner el ojo en el enjambre, más sangre en la herida. Lo válido ahora son los parches en la eternidad. Entonces, rómpete para nunca la crisma contra el muro, la sangre con letra entra, con el mundo la letra entra en la sangre.

Algo para alguien (nosotros, aquellos, muertos, redivivos, míseros y esplendentes átomos) debemos escribir -a cuchilladas y a besossobre los únicos huesos vivos humanos que nos quedan".

Marcados por esta impronta se manifiestan los textos poéticos de "Sudario" (poemas escritos entre 1986 y 1993), la primera parte de Anverso carnal de las estrellas, en el cual el discurso metapoético es convocado a propósito de una reflexión sobre el proceso de la escritura y de la lectura. Entre los poemas, "Libro" destaca la función especular del texto artístico a partir de una serie de juegos de perspectivas que homologan los diferentes planos en que se visualiza este autor respecto de su actividad poética y crítica; así se plantea el texto como la inscripción de un autorretrato frente al cual el emisor textual cumple una doble función, por una parte, como mediador de la representación del sujeto textual e instancia autocrítica que señala el "estado del arte", y, por otra, como intérprete de lo representado, asumiendo el rol de lector.

"Sólo puedo leer tu cara, huenún jaime luis,/ sietemesino feo, sólo/ puedo leer tu mitad hijo, / tu mitad hueso y calavera encarnada / tu débil número negativo/ hecho de cuarteada eternidad / y carne./ / Sólo puedo leer tu mitad / padre, hermano, aquel / que diariamente sale a conseguir/ una mísera ración de estrellas, exiguo alimento / de palabras que no saben todavía ni/ siquiera balbucear./ / Sólo puedo leerte al lado del Otro,/ sólo junto a los conjuntos rotos de tu 
madre,/ sólo solitario pero nunca solo,/mal ladrón de la blancura de las Páginas..."

Si bien el texto se encarga de ocultar el proceso escritural que le ha dado origen en tanto "libro", y su estructura se orienta a relevar el plano del lector haciéndolo corresponder a un ejercicio subjetivo y parcial de los significados, y a mostrar una incapacidad para comprender al sujeto textual en su actividad poética:

“...sólo puedo leer la mitad/ del aire que te hace viejo,/ la otra mitad la ganas/ con el sudor de tus ojos / y aquello / no tiene explicación en mi/alfabeto".

Lo que se lee a través de la caracterización irónica que se ha realizado del sujeto textual es, mediante homología, al propio autor y a su escritura, al cual este emisor califica en su lenguaje como "palabras que no saben todavía ni/siquiera balbucear" y al propio autor como "mal ladrón de las blancuras de la Páginas"; apuntando el texto, con estos procedimientos, a su propia deslegitimación como construcción artística, al poner en crisis la competencia escritural e interpretativa que le da origen y sentido.

Es este nombrar en las páginas en blanco, escritura y nombrar siempre y solo la mitad, el sentido que orienta al texto en el encuentro-desencuentro con el "otro", sí mismo como otro y diverso en los espacios no resueltos de su mestizaje y de un proyecto poético que busca morada en el lenguaje, un lenguaje a través de otros lenguajes, y también de la mitad lenguaje y nombre de lo otro -lo innombrado- en el duelo político del país.

Mediante este juego de perspectivas, este poema se ubica en el centro del movimiento hermenéutico de una comprensión e interpretación sobre el lenguaje y la actividad poética, que vuelve a reiterar el sentido conflictivo de "la palabra" que ya se indicaba en el texto"Portada".

Sin embargo, la articulación entre este sentido reflexivo sobre la actividad poética y el carácter dialógico de su proyecto se ve enfatizada desde otro punto de vista en el poema "Después de leer tanto a César Vallejo", donde este escritor busca a través de la intertextualidad demarcar su territorio conceptual al amparo de una tradición de lecturas que han impregnado su camino en la poesía, estableciendo un diálogo conflictivo y próximo con Vallejo y su obra, especialmente a través de las alusiones a "Piedra negra sobre una piedra blanca", "Los dados eternos" y el poema "XXXVI" 
(Trilce), refrendando ya una posición estética que se centra en la recuperación de su identidad indígena y que se afianza en Ceremonias:

"El mundo se concentra en tu índice, César/y acusa a mis poemas de no tener/ ni la más remota filiación / con tus jueves parisinos. / / Ah, no sabes cuán indiferente me es Dios/y nunca podrías medir el gran esfuerzo, / que mis poemas hacen por llegar a ser dignos hijos suyos./ / ...También que soy fiel discípulo tuyo en todo / lo que tenga relación con aquello / de no amar mis manos, / sino hasta que les nazca a cada una/ el sexto hermoso dedo que les falta/ / No sé, Cholo... bueno sé/ que no bastan las disculpas / por usar tus letras -tus sagradas pertenencias-/ sin tu legal y expresa autorización, /ipero, hombre...me estoy jugando / tu noche de ayer y mi día de mañana/ a un número y a un dado/ que aún no acaba de rodar!..."

En contrapunto con "Sudario", "Al anverso carnal de las estrellas”, la segunda parte de este inédito que lleva el mismo nombre plantea la apertura a un mundo cifrado por la intermediación del contacto interétnico, un hablar poético abierto al viaje de la recuperación de la memoria ancestral y de la memoria de lo violentado, el viaje para observar desde las claves de la cultura originaria la vivencia de la raíz indígena y desde los ojos del cronista, la vivencia de la intervención cultural, desdibujando la crónica oficial y con ello la historia contada para reescribirla desde los que no han tenido voz.

Es esta textura la que da origen a Ceremonias (1999), textura compuesta tanto por la unión del conjunto de poemas que "Al anverso..." provee a esta nueva propuesta, como por la decantación de una actitud dialógica y panóptica que busca afirmar en el juego discursivo el sentido de su andar poético. Así, Ceremonias logra ser un libro que "deviene nütram", como bien señala Sergio Mansilla en el Prólogo de la publicación, describiendo en Huenún esta "conciencia de saberse poeta conversador, dialogante..." que es representada a través de "un conjunto de sujetos que toman la palabra y hablan desde sus propias unicidades y puntos de vista; pero todos situados en el conflictivo y deslumbrante cruce entre indígenas y no indígenas, vivos y muertos, hechos y sueños, la tierra de abajo y la tierra de arriba".

$\mathrm{Si}$ "el verdadero diálogo con el Poema único de un poeta es el diálogo entre poetas", como señalara Heidegger, es a través de su segunda 
publicación, Puerto Trakl (2001), que Huenún planteará con pleno dominio un discurso metapoético en esta dirección. Así, Puerto Trakl responde a un proyecto que se orienta como diálogo con la poesía universal, a la que pone en cuestionamiento, y de la que busca desasirse para ir al encuentro de su propio hablar poético.

Es este libro la metáfora del descenso del poeta errante al mundo de las sombras, homologando la travesía del pensamiento occidental anclada en la referencia platónica, y de una poética que ve en Trakl, Melville, Rilke y su tradición, la reiteración de un viaje a un mundo degradado, ficticio, circular e inútil; desde el cual solo cabe vislumbrar la salida, ruptura de lo dialogado, por un cierto realismo anclado en el estado originario de las cosas y del permanente ejercicio de su cotidianeidad.

Ubicado en el centro de la referencia poética, el nombrar poético de Trakl abre metafóricamente la puerta de "la noche" velada en que se sostiene el caminante:

"Bajé a puerto Trakl entre neblinas./Buscaba el bar de la buena suerte para charlar sobre la travesía".

Sin embargo, el camino para el encuentro con los otros, como esperanza y certeza de comunión, se ve prontamente truncado por el carácter desvinculante que adquiere la presencia de ese "otro" al proponerse a sí mismo como un "yo" pleno de subjetividad:

"Pero todos miraban la estrella polar en sus copas, mudos como el mar frente a una isla desierta.../ A Puerto Trakl los poetas vienen a morir, me dijeron / sonriendo en todos los idiomas del mundo. / Yo les dejé poemas que pensaba llevar a mi tumba / como prueba de mi paso por la tierra..."

Ante un mundo que va transformando a los viajeros en apátridas, seres sin nombre y sin voz, surgen los discursos de llamado y de advertencias, con una función de anclaje en el afuera y posibilitando las opciones del sujeto: dejar de ser sí mismo en el camino de la identificación poética o la elección de la soledad:

““'Y si vienes a morir a Puerto Trakl, / no bebas de mi vino", dijo el tabernero" (7)

"Aparta el mal de tu vida", decía el capellán/ en el servicio del zarpe" (9). 
La travesía se convierte entonces en un viaje hacia la contemplación de sí mismo, hacia atrás, proyectando el adentrarse al futuro, retrospección e introspección:

"Como una manera triste de predecir / miro el paso de las nubes sobre el puerto:/ Sé que mi suerte no está/ en ninguno de esos nimbos que regresan al mar/movidos apenas por el viento de la literatura..."

Sumido en este espacio circular, el texto se abre al registro de lo sucedido como anotación de una bitácora de viaje, aludiendo a Melville; donde el puerto, metáfora del navío, es el destino común de una tripulación enajenada de soledad y miseria en un mundo clausurado por su ritual.

Solo la reflexión del "yo" hacia la exterioridad, el recuerdo y su proyección como apertura a los otros moviliza las advertencias, y las voces poéticas se cierran sobre sí ante la conciencia de su despertar. Surge un hablar pleno de sarcasmo sobre la condición de haber teatralizado su propio devenir: la puesta en escena de un cierto romanticismo que ve en su sufrimiento la autocomplacencia.

"Como un cantante de ferias y cantinas / repitiendo siempre las mismas canciones, / declamo poemas al océano./ El oleaje apaga el rumor de mi voz/ y la espuma salpica estos papeles / como un escupitajo de las rocas y del agua/ a mi vanidad./ Entonces imito el gesto del cantante / cuando extiende la guitarra al público y le dice:/ "no quiero aplausos, sólo monedas, / no quiero aplausos, sólo monedas"

La salida de este laberinto es asumida en la conciencia de estar en lo cotidiano, y lo cotidiano es la certeza de haber salido de las imágenes y "los objetos pintados sobre la superficie de las aguas", es la certeza de percibir los objetos mismos y acceder al plano del conocimiento de aquello que daba origen a las sombras.

"Otra tierra ha de hallarse mejor que esta colina,/ mejor que esta bahía donde muere la luz./ Otra tierra ha de hallarse donde el pan sepa a pan/ y no a sudor de hombres sin patria y/ sin destino"

Es la despedida del hablar poético de Tralk, también metáfora de otros diálogos con la poesía universal en que se ha remitido a un concepto de ser 
poeta y de un hablar poético en andanza en medio del resplandor, las sombras, los fantasmas, el dolor y el desencanto, y es, a su vez, el retorno a la soledad del caminante que se asoma a la naciente luz, la salida del umbral para dar paso a su abandono definitivo en otra tierra donde "el pan sepa a pan".

"Ninguna mano despide tus ojos,/ ninguna piel aguarda tu regreso./ $\mathrm{Tu}$ nombre, lo sabes, es una moneda/ tirada con furia a los sitios eriazos./ Recuerda la nieve cayendo a los pinos,/ ahora que deambulas al garete por un puerto / nublado y solitario, tenebroso y/ ficticio.// Ebrio me despide Puerto Trakl/ con el alba mojando mi cabeza./ Sin dinero, sin amigos y sin reputación/ vuelvo a mis antiguos días./ La pequeña mañana abre sus puertas./ Los tugurios donde beben poetas y pescadores/ quedan para siempre atrás".

Aunque en la propuesta de Puerto Trakl pareciera desplegarse un hablar poético y una reflexión de un proyecto poético anterior a Ceremonias, lo cierto es que, siendo bastante posterior, forma parte de un proceso reflexivo que constantemente vuelve su mirada hacia el "otro", donde reafirmar su andar en "la perdida lengua huilliche".

\section{ENTRETEXTOS III: LOS RASGOS DE UN DISCURSO DE INDIGENIDAD EN EL DIÁLOGO POÉTICO INTERCULTURAL}

Haciendo referencia al proceso traduccional que establece actualmente el discurso poético mapuche, a partir de los procedimientos transtextuales antes vistos, se puede señalar que se torna evidente en él un desplazamiento gradual de la perspectiva dialógica intercultural desde la cual surge para posicionar como centro de su articulación textual un "discurso de indigenidad". En este sentido, este discurso busca construir sus propios argumentos con que afirmar la condición de la diferencia cultural, la denuncia de los atropellos históricos y el rescate de los elementos ancestrales; y lo hace a través de los diversos recursos y mecanismos discursivos que tanto el canon poético como el canon cultural le permiten vincular y reformular con este propósito. En la práctica, esto es la construcción de una serie de trayectos isotópicos y estructurales que se orientan al plano simbolizador del discurso, y de los proyectos poéticos en su conjunto, tendiente a la organización de un sistema poético con una identidad discursiva y cultural propia. 
Si este sistema se encuentra en una fase de elaboración o de reactualización porque está ya constituido, es una interrogante a la cual todavía no podemos dar respuesta; sin embargo, se puede afirmar que este proceso resulta indicador de lo que sucede también con otros discursos que se ubican en la intersección enunciativa de un diálogo intercultural asimétrico, ante el cual se busca estratégicamente proponer elementos discursivos que reviertan el predominio de un sistema comunicativo impuesto y legitimado por la cultura dominante. En esta dirección, se hace indudable que este camino por la recuperación y visibilización de lo propio corresponde a un proceso lento y complejo, donde no solo se acogen recursos de la cultura ajena, sino también recursos de la tradición propia y ancestral, los cuales son dinamizados en el espacio discursivo mediante procedimientos de apropiación, innovación o conservación cultural.

Se establece entonces el discurso, y extensivamente cada proyecto poético, como un espacio fronterizo y de traducción cultural donde se reafirma o se construye una identidad cultural propia relacionada con la cultura tradicional y un sistema discursivo que la represente; allí, el sentido de los procedimientos de transtextualidad como estrategia discursiva resulta ser cómo se resuelve la limitación del discurso impuesto, la del discurso escritural, caracterizado por su linealidad y unidireccional, su eje temporal diacrónico y espacialmente estático, para trascenderlo dialógica y sincrónicamente desde los códigos culturales que se busca representar. Desde este punto de vista, se moviliza el discurso hacia los elementos culturales a partir de una visión temporal compleja, que corresponde a veces a una lógica cultural tradicional cíclica y ahistórica en la que inserta el desplazamiento diacrónico, o que se articula con el presente insertando un sujeto que evalúa su pasado cultural desde la contingencia.

Mediante estos procedimientos, el discurso poético mapuche estrategiza y representa una lógica de la transformación intercultural asociada con el reestablecimiento del orden natural del ethos cultural quebrado por la intervención histórico-política, la compensación de los mecanismos de invisibilización del sujeto indígena establecidos por el discurso colonizador, la legitimidad del préstamo y la innovación cultural como estrategia de pervivencia cultural, entre otras, cuya finalidad es la apertura a un sistema de comunicación intercultural de carácter simétrico.

"No sólo los elementos pertenecientes a diferentes tradiciones culturales históricas y étnicas, sino también los constantes 
diálogos intratextuales entre géneros y ordenamientos estructurales de diversa orientación, forman ese juego interno de recursos semióticos, que, manifestándose, con la mayor claridad en los textos artísticos, resulta, en realidad, una propiedad de todo texto complejo. Precisamente esa propiedad hace al texto un generador de sentido, y no sólo un recipiente pasivo de sentidos colocados en él desde fuera" (Lotman: 86).

\section{BIBLIOGRAFÍA}

Aniñir Quilitraro, David. Mapurbe. Venganza a raiz. Primera edición. Producción editorial Lord Carter (La Lle’a). Santiago, Chile: Talleres Gráficos "El Sindicato", 2005.

Bhabha, Homi. El lugar de la cultura. Buenos Aires, Argentina: Manatial, 2002.

Carrasco, Hugo. "Poesía Mapuche Actual: de la apropiación hacia la innovación cultural". Revista Chilena de Literatura. 43:76-87. Depto. Literatura. Universidad de Chile, Santiago de Chile, 1993.

Carrasco, Iván. "Etnoliteratura mapuche y literatura chilena: relaciones". Actas de Lengua y Literatura Mapuche $\mathrm{N}^{\circ}$ 4. Depto. Lenguas y Literatura. Universidad de La Frontera, Temuco, Chile, 1990.

Carrasco, Iván. "La poesía etnocultural en el contexto de la globalización” Revista de Crítica Literaria Latinoamericana. Año XXIX, №58. Lima-Hanover, pp.175-192. 2003.

Colipán, Bernardo. Arco de Interrogaciones. Santiago, Chile: LOM Ediciones, 2005.

Contreras, Verónica. "Un viaje a la memoria en la escritura poética de Elicura Chihuailaf". Lengua y Literatura Mapuche 7. Vol I. Universidad de La Frontera, 1996.

Cozzi, Enzo. "Sabiduría ancestral mapuche. Conversación con el ngenpin: Armando Marileo Lefío" Revista Ecovisiones No 9. S/f. http://www.ecovisiones.cl

Chihuailaf, Elicura. En el país de la memoria Quechurewe-Temuco, 1988.

Chihuailaf, Elicura. El invierno y su imagen y otros poemas azules. Santiago, Chile: Ediciones Literatura Alternativa, 1991.

Chihuailaf, Elicura. "Mongeley mapu ñi püllü chew ñi llewmuyiñ”. Simpson 7, volumen II, Segundo Semestre. Santiago, Chile, 1992.

Chihuailaf, Elicura. De sueños azules y Contrasueños. Santiago, Chile: Editorial Universitaria y Editorial Cuarto Propio, 2000.

García B., Mabel. "Temas de resistencia cultural: "Oratorio al Seños de Pucatrihue” de César Millahueique". Lengua y Literatura Mapuche $\mathrm{N}^{\circ} 11$. Universidad de La Frontera, Temuco, Chile, 2004

García B., Mabel. "La narrativa de la "nación" en el discurso poético mapuche". Actas VI Jornadas Andinas de Literatura Latinoamericana (JALLA). Volumen I, Carlos GarcíaBendoya Editor. Universidad Nacional Mayor de San Marcos, Lima, Perú, 2005a. 
García B., Mabel. "Lenguaje, traducción y resistencia cultural en el discurso poético mapuche: "Arco de Interrogaciones" de Bernardo Colipán", pp.157-177. Papeles de Trabajo. $\mathrm{N}^{\circ} 13$. Universidad Nacional de Rosario, Rosario, Argentina, 2005b.

García B., Mabel. "Poesía mapuche: Estrategias discursivas para territorializar la diferencia cultural". Actas IV Congreso Chileno de Semiótica. Universidad de La Frontera, Temuco, Chile. 2005c (en prensa).

García B. Mabel. "César Millahueique. Correlatos y transformaciones en la recomposición cultural”. Crítica Situada. El estado actual del arte y la poesía mapuche .García B., M; Carrasco M., H. y Contreras H.,V. Mabel García, Editor. Universidad de La Frontera, Temuco, Chile: Editorial Florencia, 2005d.

García B., Mabel. "El discurso poético mapuche y su vinculación con los "temas de resistencia cultural"”. Revista Chilena de Literatura. 68: 169-197. Depto. Literatura, Universidad de Chile, Santiago, Chile, 2006.

García, M y Galindo, S. Ed. Poesía mapuche. Las raíces azules de los antepasados. Achi Kallfüküpanngen Ta Pu Kuyfikeche. Universidad de La Frontera, Temuco, Chile: Editorial Florencia, 2004.

Geeregat, Orietta y Gutierrez, Pamela. "Se ha despertado el ave de mi corazón. TextoKultrung”. Actas Lengua y Literatura Mapuche. №5. Depto. Lenguas y Literatura, Universidad de La Frontera, Temuco, Chile, 1992.

Genette, Gerard. Palimpsestos. La literatura en Segundo grado. Madrid, España: Edit. Taurus, 1989.

Huenún, Jaime. Al anverso carnal de las estrellas. Texto inédito, 1994.

Huenún, Jaime. Ceremonias. Editorial Universidad de Santiago, Santiago, Chile, 1999.

Huenún, Jaime. Puerto Trakl. Santiago, Chile: LOM Ediciones, Colección Entre Mares, Poesía, 2001.

Huinao, Graciela. Walinto. Santiago, Chile: Ediciones La garza morena, 2001.

Ibacache, J.; McFall, S. y Quidel, J. "Rume kagenmew ta az mapu. Epidemiología de la trasgresión en Makewe Pelale". Working Paper Series 2. Nuke Mapuförlaget. 2002.http:/ /www2.estudiosindigenas.cl/Medicina.htm

Lienlaf, Leonel. Se ha despertado el ave de mi corazón. Santiago, Chile: Editorial Universitaria, 1990.

Lienlaf, Leonel. Pewma dungu. Palabras soñadas. Santiago, Chile: LOM Ediciones, 2003

Lienlaf, Leonel, Yerba_Agua. Edición propia. 2006.

Lotman, Iuri. La semiósfera I Semiótica de la cultura y del texto. Madrid, España: Ediciones Cátedra, 1996.

Manquenahuel, Juan Pablo. "We txipantu, wiñotuy txipan antu, wiñoy txipantu. Mapuche kimun meu”. Recuperando sabiduría mapuche. http://www.galeon.com/mapunche/ wetripantu.html

Millahueique, César. Profecía en blanco y negro o las 125 líneas de un vuelo. Santiago. Chile: Talleres Gráficos El Arte, 1998.

Millahueique, César. Oratorio al señor de Pucatrihue. Santiago, Chile: Ediciones La estocada sorpresiva, 2004. 
Millahueique, César. Imágenes del Rito. Santiago, Chile: Ediciones La estocada sorpresiva, 2006.

Montecinos, Sonia. "Literatura mapuche: oralidad y escritura." Simpson 7. Revista de la Sociedad de Escritores de Chile. Vol. II, Segundo semestre, Santiago, Chile, 1992.

Ovalle, Alonso de. Histórica Relación del Reino de Chile (1646). Santiago, Chile: Biblioteca del Bicentenario, Pehuén Editores, 2003.

Painequeo Paillán, J. Héctor. La Oralidad en el Canto Mapuche. Tesis para optar al grado de Magister en Lingüística Indoamericana, CIESAS, Mexico. D.F., 2000.

Rosales, R.P. Diego de. Historia General del Reyno de Chile. Tomo II, Libro VI. Valparaíso: Imprenta del Mercurio, 1878.

Stavenhagen, Rodolfo. "Los derechos indígenas: algunos problemas conceptuales". Isonomía. Revista de Teoría y Filosofía del Derecho. N³. Alicante. España, 1995. Edición Biblioteca Virtual Miguel de Cervantes. 2005. http://www.cervantesvirtual.com/Ficha Obra.html?Ref $=15654$ 